\title{
Public Expenditure and Economic Growth: A Test of Wagner's and Keynes Hypotheses in Nigeria and Angola Economies
}

\author{
Saliu Mojeed Olanrewaju, and Akeju Kemi Funlayo
}

\begin{abstract}
This study verifies the validation of Wagner's theory and Keynes's hypothesis between three main government expenditure components (Health expenditure, education expenditure, and capital investment expenditure) and economic growth in Nigeria and Angola. The study employs Johansen cointegration and pairwise granger causality as the estimation techniques. Findings revealed no evidence of long-run relationships with government expenditure components of health, education, and capital investment and economic growth. The study equally reveals the validation of Wagner's theory between growth and expenditure on health in both Nigeria and Angola. Evidence that confirms both Wagner's theory and Keynes's hypothesis between growth and expenditure on education in Angola and validation of only Keynes hypothesis in Nigeria was found. Also, the study confirms the validation of Keynes's hypothesis between government expenditure on capital investment in both Nigeria and Angola.
\end{abstract}

Index Terms-public expenditure, economic growth, wagner's theory, keynes hypothesis, cointegration, granger causality

\section{INTRODUCTION}

The debate on the relationship existing between growth and government expenditure has been ongoing for decades and the rise of government expenditure across regions has necessitated the need to ascertain this relationship in the oilrich producing countries of Nigeria and Angola. Wagner's law (1883) and Keynesian hypothesis (1936) are contemporary laws that placed different views on the relationship existing between the two variables; Wagner law identified that economic growth thus promotes government expenditure whereas Keynes hypothesis is contrary to this, stating that it is government expenditure that raises economic growth. However, the debate in works of literature varies and remains inconclusive with different results emerging from empirical results on studies from. different countries with different and even similar economic backgrounds and situations.

Over the decades, public expenditure spending has increased across the world. In rich-oil countries of Nigeria and Angola, government expenditure has increased rapidly due to the rise in crude oil revenue coupled with rising demand for public goods and services such as education, road, communication, and health. Barros et al (2015) asserted that the Angolan economy is capital intensive with the oil sector dominating the economy and also constituting a challenge to the growth of other sectors. Huge receipts as

Published on May 11, 2021

Saliu Mojeed Olanrewaju, Department of Economics, Faculty of the Social Sciences, Ekiti State University, Ado-Ekiti, Nigeria.

(corresponding e-mail: mojees4real2@yahoo.com) proceeds from oil in Nigeria in the past three decades have not sufficiently raised government expenditure towards promoting growth and development.

In Nigeria, the rise of insurgency, communal clashes, and civil conflicts have increased the need to provide security for the people and the nation at large which raises gross national expenditure. The gross national expenditure as a percentage of GDP for Nigeria and Angola as of 2015 stood at $99.86 \%$ and $99.3 \%$; an indication that almost all revenue of Nigeria and Angola is spent on its expenditure. Despite the huge rise in government expenditure in Nigeria and Angola, overall economic growth and development have been very slow. GDP per capita in Nigeria stood at 2,175 at the current US dollar with an annual percentage growth of $-4.16 \%$ and that of Angola was 3,308 at the current US dollar having -3.95\% annual percentage growth in 2015(World Development Index, 2017).

The stabilization of an economy involves the operations of macroeconomic variables that anchor on fiscal policy and monetary policies of a nation. Fiscal policy centralizes focus on government expenditure and observed that it plays a major role in the redistribution of public goods and the provision of adequate goods and services. Government expenditure has been found to be dependent on revenue accruable to a country. In Angola and Nigeria, oil is the main source of export, and the recent fall in world oil prices generated and raised the effect of economic recession on such oil-rich countries. With the improvement in oil prices, countries are gradually coming out of recession with the capabilities of increased government expenditure, thus it becomes imperative to ascertain the nature and direction of causality between government expenditure and economic growth (GDP) in Nigeria and Angola.

Verification of Wagner's law and Keynes's hypothesis becomes necessary to test whether or not government expenditure and gross domestic product Granger cause each other and also ascertain if a long-run equilibrium relationship exists between them due to the persistent rise in the volume of public expenditure. Thus, renewing the growing needs to investigate and ascertain the existence of both Wagner's and Keynes's hypotheses in Nigeria and Angola as oil-producing countries.

Moreover, a large number of studies have tested Wagner's law and Keynes's hypothesis particularly in Africa (Olugbenga and Owoeye, 2007; Garba and Abdullahi 2013; Udo and Effiong 2014). However, most of the tests of these past research work for Wagner's law and Keynes's hypothesis are carried out with the use of estimations that are

Akeju Kemi Funlayo, Department of Economics, Faculty of the Social Sciences, Ekiti State University, Ado-Ekiti, Nigeria 
based on a simple regression equation which includes only GDP growth and total government expenditure. Meanwhile, equation specification of these types always leads to a specification error; as it is a stylized fact that many other factors as the components of government expenditures can also affect GDP growth apart from the total government expenditure such as health expenditure, expenditure on education, government expenditure on capital investment, expenditure on security, etc. Consequently, this research work contributes to the existing literature by disaggregating government expenditures into components of health expenditure, education expenditure, and expenditure on capital investment and ascertaining the direction of causality between them and gross domestic product growth in Nigeria and Angola.

In addition, the choice of Nigeria and Angola as our case study in this research work is borne out of the fact that these countries are the two highest producers of oil in Africa. In this regard, findings from the comparative analysis of the two countries as regards the fiscal management frameworks are capable of serving as a full generalization for the entire African oil-producing countries.

The rest of the paper consists of section two which discusses a brief review of literature that captures the conceptual, theoretical, and empirical literature. Section three covers the research method, section four presents the discussion of findings and section five discussed the conclusion and the study recommendations.

\section{LITERATURE REVIEW}

Olugbenga and Owoeye (2007) work on the relationships existing between government expenditure and growth of 30 OECD countries, using annual data from 1970-2005 found a long-run relationship between aggregate government expenditure and economic growth. Also, for only 16 countries, unidirectional causality existed, thus validating the Keynesian hypothesis. Moreover, another 10 countries result is in support evidence of Wagner's law with causality flowing from economic growth to government aggregate expenditure there.

Garba and Abdullahi (2013) Johansen co-integration and Granger causality test result with aggregate data from 1970 2008 on public expenditure and growth relationship in Nigeria revealed that public expenditure and economic growth are cointegrated in the long-run while the causality test indicates that the flow is from public expenditure to economic growth and also through economic growth towards public expenditure as against a unilateral direction.

Udo and Effiong (2014) by determining the nature and causality direction existing between government spending and economic growth found evidence to support the Wagner hypothesis on economic growth in Nigeria with 1970-2012 time-series data. The study also ascertains the nature of the relationship between the macroeconomic variables and concludes that the government should channel its expenditures toward the productive sectors to increase productivity and growth of the Nigerian economy. In like manner, Jobarteh (2017) also found empirical support for the validity of Wagner's hypothesis in the Gambia.

On the other hand, Ighodaro et al (2010) result validate Keynes' theory rather than Wagner's Law in Nigeria, using disaggregated variables of government spending on general administration, community and social services spending, and with the introduction of economic policy and political freedom as variables in the model in order to develop the functional form. Similarly, Sanches-Joares et al (2015) use five recommended specifications to test both hypotheses in Mexico and the result invalidate Wagner's Law and validate Keynes' theory.

Aniefiok and Charles (2016) on which of Wagner or Keynes theory prevails in Nigeria, considered the nature, relationship, and the direction of causality between government spending and the economic growth using the Granger causality and ordinary least square (OLS) technique. The result indicates a bidirectional relationship with government spending and economic growth, thus supporting both Wagner's and Keynesian hypotheses. Evidence of the direct effect of government expenditure on economic growth in Nigeria was also found, the paper, therefore, called for appropriate government policies on government spending towards promoting growth and development in Nigeria. Thus, to achieve sustainable economic growth, Government expenditure should be increased in the Nigerian economy.

Eldemerdash and Ahmed's (2019) paper on Wagner's law versus Keynesian hypothesis using new evidence from Egypt based on data spanning from 1980-2012 attested to the presence of cointegration existing between government expenditure and GDP. The study used the ADF-breakpoint unit root test, Pesaran, Shin et al. (2001) bounds test for cointegration, and also the Auto-Regressive Distribution Lag model to estimate the long-run relationship which run from GDP to government expenditure; thus, providing support for Wagner law. Based on the result of the analysis, the study concludes that the reduction of government expenditure can help stabilize the economic situation of Egypt without having a negative effect on growth. It also revealed that the economic effect of government expenditures on sectors of the economy must be considered to avoid any side effects of government expenditure reduction.

\section{METHODOLOGY}

\section{A. Theoretical Framework}

This paper framework, rests on Wagner's law and Keynes's hypothesis. Wagner's law which was propounded by the German economist Adolph Wagner postulates government expenditure as an endogenous factor that is influenced by a country's economic growth. This means that it is the economic growth that causes the public spending of a country. This public sector postulation is formulated mathematically as follows:

$G_{t}=f\left(y_{t}\right)$

Where $G$ represents public spending size, $Y$ refers to a country's economic performance level and t stands for time. Keynes's hypothesis is a principle that was postulated by an economist known as Keynes. Keynes described public spending as an exogenous variable that can stimulate economic growth. From Keynes's perspective, public spending can generate economic growth. In this regard, the increased government expenditure can enhance employment, investment, and profit from multiplier effects which will, in turn enhance economic growth. This postulation is formulated mathematically as:

$Y_{t}=f\left(G_{t}\right)$ 


\section{B. Model Specification}

Based on the theoretical proposition of Wagner's law and Keynes's hypothesis explained in this section, the model for this study is therefore specified in four equations as follows:

$$
\begin{aligned}
& \Delta G D P r_{t}=\sum_{k=0}^{p} \theta_{k} \Delta H E X_{t}+\sum_{k=0}^{p} \alpha_{k} \Delta E D U_{, t}+\sum_{k=0}^{p} \gamma_{k} \Delta G F C F_{t} \\
& +\sum_{k=0}^{p} \mu_{k} \Delta F D I_{t}+\sum_{k=0}^{p} \pi_{k} \Delta O I L R_{t} \\
& +\sum_{k=0}^{p} \beta_{k} \Delta U N E M P L_{, t}+\varepsilon_{t} \\
& \Delta H E X_{t}=\sum_{k=0}^{p} \theta_{k} \Delta G D P g r_{t}+\sum_{k=0}^{p} \alpha_{k} \Delta E D U_{, t}+\sum_{k=0}^{p} \gamma_{k} \Delta G F C F_{t} \\
& +\sum_{k=0}^{p} \mu_{k} \Delta F D I_{t}+\sum_{k=0}^{p} \pi_{k} \Delta O I L R_{t} \\
& +\sum_{k=0}^{p} \beta_{k} \Delta U N E M P L_{, t}+\varepsilon_{t} \\
& \Delta E D U_{t}=\sum_{k=0}^{p} \theta_{k} \Delta G D P g r_{t}+\sum_{k=0}^{p} \alpha_{k} \Delta H E X_{t}+\sum_{k=0}^{p} \gamma_{k} \Delta G F C F_{t} \\
& +\sum_{k=0}^{p} \mu_{k} \Delta F D I_{t}+\sum_{k=0}^{p} \pi_{k} \Delta O I L R_{t} \\
& +\sum_{k=0}^{p} \beta_{k} \Delta U N E M P L_{, t}+\varepsilon_{t} \\
& \Delta G F C F_{t}=\sum_{k=0}^{p} \theta_{k} \Delta G D P g r_{t}+\sum_{k=0}^{p} \alpha_{k} \Delta H E X_{t}+\sum_{k=0}^{p} \gamma_{k} \Delta E D U_{t} \\
& +\sum_{k=0}^{p} \mu_{k} \Delta F D I_{t}+\sum_{k=0}^{p} \pi_{k} \Delta O I L R_{t} \\
& +\sum_{k=0}^{p} \beta_{k} \Delta U N E M P L_{, t}+\varepsilon_{t}
\end{aligned}
$$

Where:

GDPgr is the Gross Domestic Product growth rate

HEX is the Health Expenditure

EDU is the Expenditure on Education

GFCF is the Expenditure on Capital Investment proxied by

Gross Fixed Capital Formation

FDI is the Foreign Direct Investment

OILR is the Oil Revenue

UNEMPL is the Unemployment Rate

$\varepsilon_{t}$ is the vector error term.

TABLE I: DESCRIPTION OF VARIABLES

\begin{tabular}{|l|l|l|}
\hline S/N & VARIABLES & DESCRIPTION \\
\hline 1. & $\begin{array}{l}\text { Gross Domestic } \\
\text { Product Growth } \\
\text { Rate (GDPgr) }\end{array}$ & $\begin{array}{l}\text { This is the annual percentage growth rate } \\
\text { of GDP at market prices based on constant } \\
\text { local currency. }\end{array}$ \\
\hline 2. & $\begin{array}{l}\text { Health Expenditure } \\
\text { (HEX) }\end{array}$ & $\begin{array}{l}\text { This represents the sum of public health } \\
\text { expenditure. It captures the provision of } \\
\text { health services, family planning activities, } \\
\text { nutrient activities and emergency aid. It is } \\
\text { expressed as a percentage of GDP. }\end{array}$ \\
\hline 3. & $\begin{array}{l}\text { Expenditure on } \\
\text { Education (EDU) }\end{array}$ & $\begin{array}{l}\text { This is the aggregate government } \\
\text { expenditure on education which is } \\
\text { expressed as a percentage of GDP. }\end{array}$ \\
\hline 4 & $\begin{array}{l}\text { Gross Fixed Capital } \\
\text { Formation (GFCF) }\end{array}$ & $\begin{array}{l}\text { This represents government investment } \\
\text { which includes purchases of plant, } \\
\text { machinery, and equipment and } \\
\text { construction of roads, railways, airports, }\end{array}$ \\
\hline
\end{tabular}

\begin{tabular}{|l|l|l|}
\hline & & $\begin{array}{l}\text { etc. It is expressed as the percentage of } \\
\text { GDP }\end{array}$ \\
\hline 5. & $\begin{array}{l}\text { Foreign Direct } \\
\text { Investment (FDI) }\end{array}$ & $\begin{array}{l}\text { This represents the net inflows of } \\
\text { investment into the economy. It is } \\
\text { expressed as the percentage of GDP. }\end{array}$ \\
\hline 6. & $\begin{array}{l}\text { Oil Revenue } \\
\text { (OILR) }\end{array}$ & $\begin{array}{l}\text { This represents the cash receipts from the } \\
\text { proceeds of oil. It is expressed as the } \\
\text { percentage of GDP. }\end{array}$ \\
\hline 7. & $\begin{array}{l}\text { Unemployment } \\
\text { Rate (UNEMPL) }\end{array}$ & $\begin{array}{l}\text { This represents the share of the labour } \\
\text { force that is without work but available for } \\
\text { and seeking employment. It is expressed } \\
\text { as the percentage of the total labour force. }\end{array}$ \\
\hline
\end{tabular}

\section{Sources of Data}

The data for this study consists of annual time series spanning from 1990 to 2017. Data on Education expenditure are sourced from United Nations Educational Scientific and Cultural Organization (UNESCO) Institute for Statistics for the two countries (i.e Nigeria and Angola). Data on Gross Domestic Product growth rate (GDPgr), Health Expenditure (HEX), Expenditure on Capital Investment (GFCF), Foreign Direct Investment (FDI) and Unemployment Rate (UNEMPL) are sourced from World Bank (WDI), while data on Oil Revenue are sourced from International Monetary Fund (IMF) statistical bulletin.

\section{RESULTS AND DisCUSSIONS}

\section{A. Results of the Unit Root Tests}

This particular section assesses the individual nature of the variables through the unit root test known as the test of variables stationarity. We use the Phillip-Perron Unit root test to ascertain the order of integration of variables. The PhillipPerron Unit root test result is presented in table 2 and 3:

TABLE II: PHILIP-PERRON UNIT ROOT TEST FOR NIGERIA

\begin{tabular}{|l|l|l|l|}
\hline \multirow{2}{*}{ Variables } & \multicolumn{3}{|c|}{ Philip-Perron Unit Root Test } \\
\cline { 2 - 4 } & T-statistics & P-value & Order of Integration \\
\hline HEX & -8.084 & $0.0000 * * *$ & $\mathrm{I}(1)$ \\
\hline EDU & -6.203 & $0.0000 * * *$ & $\mathrm{I}(1)$ \\
\hline GFCF & -4.697 & $0.0000 * * *$ & $\mathrm{I}(1)$ \\
\hline GDPgr & -9.409 & $0.0000^{* * *}$ & $\mathrm{I}(1)$ \\
\hline OILR & -4.414 & $0.0021 * * *$ & $\mathrm{I}(1)$ \\
\hline FDI & -5.781 & $0.0000 * * *$ & $\mathrm{I}(1)$ \\
\hline UNEMPL & -4.893 & $0.0043 * * *$ & $\mathrm{I}(1)$ \\
\hline
\end{tabular}

Source: Author's Computation

$(* * *)$ refers to the statistical significance at $1 \%$. Each model includes trends and constant terms. 
TABLE III: PHILIP-PERRON UNIT ROOT TEST FOR ANGOLA

\begin{tabular}{|l|l|l|l|}
\hline \multirow{2}{*}{ Variables } & \multicolumn{3}{|c|}{ Philip-Perron Unit Root Test } \\
\cline { 2 - 4 } & T-statistics & P-value & Order of Integration \\
\hline HEX & -8.691 & $0.0000^{* * *}$ & $\mathrm{I}(1)$ \\
\hline EDU & -6.278 & $0.0000^{* * *}$ & $\mathrm{I}(1)$ \\
\hline GFCF & -6.884 & $0.0000^{* * *}$ & $\mathrm{I}(1)$ \\
\hline GDPgr & -4.990 & $0.0002 * * *$ & $\mathrm{I}(1)$ \\
\hline OILR & -7.079 & $0.0021 * * *$ & $\mathrm{I}(1)$ \\
\hline FDI & -7.855 & $0.0000^{* * *}$ & $\mathrm{I}(1)$ \\
\hline UNEMPL & -8.145 & $0.0000^{* * *}$ & $\mathrm{I}(1)$ \\
\hline
\end{tabular}

Source: Author's Computation

$(* * *)$ refers to the statistical significance at $1 \%$. Each model includes trend and constant term.

Results in table 2 and 3 above, shows that at a $1 \%$ level of significance, all the variables are non-stationary at levels, but are stationary at their first difference for both Nigeria and Angola. The indication of this is that all the variables are integrated of order one i.e I(1).

\section{B. Johansen Cointegration Test}

Since it has been established in the unit root test that the variables are integrated of order one, I(1), it is therefore very necessary to ascertain the cointegrating relationship existing among the variables so as to know the fitness in the use of Granger causality or Vector Error Correction Mechanism (VECM). According to Sims (1980), VECM is often appropriately used when the long-run relationship can be specifically ascertained. He equally posited that if the precise cointegrating relationship cannot be established among the variables, the use of a pairwise granger causality test or Vector Autoregressive (VAR) model is appropriate as they give consistent estimates. Thus, the Johansen Cointegration tests for this purpose are presented in the table 4 and 5 .

TABLE IV: JOHANSEN COINTEGRATION TEST FOR NIGERIA

\begin{tabular}{|l|l|l|l|}
\hline Maximum Rank & Eigenvalue & Trace Statistics & 5\% Critical Value \\
\hline 0 & - & 128.6932 & 156.00 \\
\hline 1 & 0.99715 & 106.2921 & 124.24 \\
\hline 2 & 0.96928 & 85.7375 & 94.15 \\
\hline 3 & & & \\
\hline 4 & 0.95913 & 42.6092 & 68.52 \\
\hline 5 & 0.77049 & 34.3422 & 47.21 \\
\hline 6 & 0.64806 & 27.1903 & 29.68 \\
\hline 7 & 0.50975 & 13.6563 & 15.41 \\
\hline
\end{tabular}

Source: Author's Computation
TABLE V: JOHANSEN COINTEGRATION TEST FOR ANGOLA

\begin{tabular}{|l|l|l|l|}
\hline Maximum Rank & Eigenvalue & Trace Statistics & $5 \%$ Critical Value \\
\hline 0 & - & 132.1815 & 156.00 \\
\hline 1 & 0.99766 & 104.6447 & 124.24 \\
\hline 2 & 0.99353 & 43.6447 & 94.15 \\
\hline 3 & 0.98597 & 32.6483 & 68.52 \\
\hline 4 & 0.86936 & 39.7312 & 47.21 \\
\hline 5 & 0.85527 & 29.4761 & 29.68 \\
\hline 6 & 0.45185 & 13.8447 & 15.41 \\
\hline 7 & 0.39517 & 0.7717 & 3.76 \\
\hline
\end{tabular}

Source: Author's Computation

Tables 4 and 5 above show the results of the Johansen cointegration test for Nigeria and Angola respectively. From the results in the two tables, it is revealed that the values of all vectors in the trace statistics are less than the critical values at a $5 \%$ level of significance for the two countries (i.e Nigeria and Angola). The study therefore, accepts the null hypothesis of no long-run relationship among all the variables during the period under review for both Nigeria and Angola.

\section{Granger Causality Estimation Results}

In a bid to assess the direction of causality between economic growth and the three components of government expenditure in this study; pairwise granger causality is adopted for the two selected African countries. Moreover, since the precise long-run relationship cannot be established in the Johansen cointegration tests among the selected variables, therefore, the adoption of pairwise granger causality in this research work is appropriate and justifiable following the position of Sims (1980).

TABLE VI: PAIRWISE GRANGER CAUSALITY TEST RESULTS FOR NIGERIA

\begin{tabular}{|l|l|l|l|}
\hline Null Hypothesis & $\begin{array}{l}\text { F- } \\
\text { statistics }\end{array}$ & Probability & Decision \\
\hline $\begin{array}{l}\text { HEX does not granger cause } \\
\text { GDPgr } \\
\text { GDPgr does not granger cause } \\
\text { HEX }\end{array}$ & 0.16990 & 0.1818 & Accept \\
\hline $\begin{array}{l}\text { GDPgr does not granger cause } \\
\text { EDU } \\
\text { EDU does not granger cause } \\
\text { GDPgr }\end{array}$ & 0.15234 & 0.8605 & Reject \\
\hline $\begin{array}{l}\text { GFCF does not granger cause } \\
\text { GDPgr } \\
\text { GDPgr does not granger cause } \\
\text { GFCF }\end{array}$ & 11.91920 & 0.0028 & Reject \\
\hline $\begin{array}{l}\text { HEX does not granger cause } \\
\text { EDU } \\
\text { EDU does not granger cause } \\
\text { HEX }\end{array}$ & 0.15490 & 0.8583 & Reject \\
\hline
\end{tabular}




\begin{tabular}{|l|l|l|l|}
\hline $\begin{array}{l}\text { GDPgr does not granger cause } \\
\text { FDI }\end{array}$ & 1.78041 & 0.2139 & Accept \\
$\begin{array}{l}\text { FDI does not granger cause } \\
\text { GDPr }\end{array}$ & 1.08171 & 0.3725 & Accept \\
\hline $\begin{array}{l}\text { OILR does not granger cause } \\
\text { GFCF } \\
\text { GFCF does not granger cause } \\
\text { OILR }\end{array}$ & 0.13432 & 0.1458 & Accept \\
\hline $\begin{array}{l}\text { UNEMPL does not granger } \\
\text { cause HEX } \\
\text { HEX does not granger cause } \\
\text { UNEMPL }\end{array}$ & 11.01398 & 0.0013 & Reject \\
\hline
\end{tabular}

Source: Author's Computation

TABLE VII: PAIRWISE GRANGER CAUSALITY TEST RESULTS FOR ANGOLA

\begin{tabular}{|c|c|c|c|}
\hline Null Hypothesis & F-statistics & Probability & Decision \\
\hline $\begin{array}{l}\text { HEX does not granger } \\
\text { cause GDPgr } \\
\text { GDPgr does not } \\
\text { granger cause HEX }\end{array}$ & $\begin{array}{l}0.44557 \\
10.26328\end{array}$ & 0.1140 & Reject \\
\hline $\begin{array}{l}\text { GDPgr does not } \\
\text { granger cause EDU } \\
\text { EDU does not granger } \\
\text { cause GDPgr }\end{array}$ & 8.84952 & $\begin{array}{l}0.0039 \\
0.0015\end{array}$ & $\begin{array}{l}\text { Reject } \\
\text { Reject }\end{array}$ \\
\hline $\begin{array}{l}\text { GFCF does not } \\
\text { granger cause GDPgr } \\
\text { GDPgr does not } \\
\text { granger cause GFCF }\end{array}$ & 12.55231 & 0.0011 & Reject \\
\hline $\begin{array}{l}\text { HEX does not granger } \\
\text { cause EDU } \\
\text { EDU does not granger } \\
\text { cause HEX }\end{array}$ & 10.45567 & 0.0015 & Reject \\
\hline $\begin{array}{l}\text { GDPgr does not } \\
\text { granger cause FDI } \\
\text { FDI does not granger } \\
\text { cause GDPgr }\end{array}$ & 10.98635 & 0.0147 & Reject \\
\hline $\begin{array}{l}\text { OILR does not } \\
\text { granger cause GFCF } \\
\text { GFCF does not } \\
\text { granger cause OILR }\end{array}$ & 8.73552 & 0.0213 & Reject \\
\hline $\begin{array}{l}\text { UNEMPL does not } \\
\text { granger cause HEX } \\
\text { HEX does not granger } \\
\text { cause UNEMPL }\end{array}$ & 7.52077 & 0.0087 & Reject \\
\hline
\end{tabular}

Source: Author's Computation

Tables 6 and 7 above show the pairwise granger causality results for Nigeria and Angola respectively. The results from the two tables reveal that there is unidirectional causality between Health Expenditure (HEX) and Economic growth (GDPgr) for both Nigeria and Angola. From the results, causality only runs from GDPgr to HEX but causality fails to run from HEX to GDPgr in the two selected countries. The implication of this finding is that there is a validation of Wagner's proposition between economic growth and government spending on the health sector of both Nigeria and Angola. The findings further corroborate the assertion of Khan (2015) that a robust economic situation in a country stimulates the purchase of new technical equipment and the expansion of health care services.

However, our results show a different direction of causality between economic growth (GDPgr) and expenditure on education (EDU) for Nigeria and Angola. From the result, there is bidirectional causality between GDPgr and EDU in Angola as the two variables (EDU and GDPgr) granger cause each other. The findings actually indicate the validation of both Keynes's hypothesis and Wagner's theory between economic growth and government expenditure on the education sector in Angola. The findings further imply that the spending on education in Angola has been able to translate to a robust economic growth while the healthy economic growth has given much back to the educational sector in terms of funding. But the case is quite different in Nigeria as there is only a validation of Keynes's hypothesis because expenditure on education (EDU) granger cause economic growth (GDPgr) while causality fails to run from GDPgr to EDU. The reason for non-causality from GDPgr to EDU in Nigeria can be hinged on the failure of the Nigerian government to spend effectively on the educational sector. This is equally a pointer to the inability of the Nigerian government to meet up with the minimum specification of UNESCO educational budget requirement of $26 \%$ every year. The United Nation Educational Scientific and Cultural Organization (UNESCO) made a benchmark of $26 \%$ of the national budget for government expenditure on education, but the Nigerian government was able to allocate just $7.38 \%$ of the national budget on the educational sector in 2017 which is far below the minimum requirement (CBN, 2017).

Moreover, the results from Tables 6 and 7 equally depict that there is unidirectional causality between economic growth (GDPgr) and expenditure on capital investment (GFCF) for both Nigeria and Angola. The results show that GFCF granger causes GDPgr while causality fails to run from GDPgr to GFCF in both Nigeria and Angola. Findings from these results imply that there is a confirmation of the presence of Keynes Hypothesis in the capital investment sector of both Nigeria and Angola. The finding is equally an indication that capital formation in the area of infrastructure development enhances the rate of economic growth in both Nigeria and Angola (Ajao, 2011).

Another very important finding from the results in table 6 and 7 is that EDU granger cause HEX while causality fails to run from HEX to EDU, indicating a unidirectional causality between spending on health and expenditure on education in both Nigeria and Angola. This finding aligns with the position of Schulz (2004), who asserts that effective spending on education can produce more individuals with higher levels of education who in turn show healthier behaviour by spending more on medical check-ups.

Also, results from Tables 6 and 7 reveal that there is bidirectional causality between foreign direct investment (FDI) and economic growth (GDPgr) of in Angola, as GDPgr and FDI Granger cause each other. The case is quite different in Nigeria as there is no direction of causality between FDI and GDPgr. The reason for the failure of causality to run from GDPgr to FDI might be attributed to the unfavourable macroeconomic environment in Nigeria that inhibits higher return on investment which in turn discourages foreign investors. Likewise, the inability of FDI to granger cause 
GDPgr might be due to the insufficient FDI fund into the Nigerian economy which has not been able to stimulate economic growth.

Furthermore, there is a unidirectional causality between oil revenue (OILR) and government spending on capital investment (GFCF) in Angola as OILR granger cause GFCF while causality fails to run from GFCF to OILR. This is an indication that oil as major revenue in Angola is one of the means Angola government devises to enhance government expenditure on infrastructures. But the reverse is the case in Nigeria because there is no direction of causality between OILR and GFCF. This is an indication that despite huge revenue generated from the oil sector in Nigeria, the infrastructure, and social capital development remains poor.

Results from Tables 6 and 7 also exhibit a unidirectional causality from unemployment rate to health expenditure in both Nigeria and Angola. The results reveal that the unemployment rate (UNEMPL) granger causes health expenditure (HEX), while causality fails to run from HEX to UNEMPL in Nigeria and Angola. Finding from these results imply that the absence of prospects to secure a job by individuals could have an adverse impact on health behaviour such as depression which could influence the demand for health care services.

\section{CONCLUSION}

Based on the results and findings in this research work, the study, therefore, concludes as follows: First, no long-run relationship exist with any of the three components of government expenditure (i.e Health expenditure, expenditure on education, and expenditure on capital investment) and economic growth in both Nigeria and Angola during the period under review. Second, there is a validation of Wagner's theory between health expenditure and economic growth in both Nigeria and Angola. Third, there is confirmation of evidence of both Wagner's theory and Keynes's hypothesis between the government spending on education and economic growth in Angola, while there is only a validation of Keynes's hypothesis between expenditure on education and economic growth in Nigeria. Lastly, there is a validation of Keynes's hypothesis between economic growth and government expenditure on capital investment in both Nigeria and Angola.

\section{REFERENCES}

[1] Ajao MG, (2011) Stock market development capital formation and growth in Nigeria. International Journal of Current Research. 33(6): 382-388.

[2] Barros CP, Alana LG, Faria JR (2015) The macro economy of Angola: breaks and persistence in Angolan macro data. Applied Economics 47(27):2783-2802

[3] Eldemerdash H, Ahmed KI (2019) Wagner's law versus Keynesian hypothesis: new evidence from Egypt. International Journal of Arts and Commerce, 8(3):1-18.

[4] Garba T, Abdullahi SY (2013) Public expenditure and economic growth: an application of cointegration and granger causality tests on Nigeria. Journal of Economic and Social Research 1-30.

[5] Ighodaro CA, Okiakhi DE (2010) Does the relationship between government expenditure and economic growth follow Wagner's law in Nigeria? Annals of University of Petrosani Economics 10(2):185198

[6] Jobarteh M (2017). Testing Wagner's law for The Gambia: 1977 2013. Munich Personal RePEc Archive paper No. 76303
[7] Keynes JM 1936. The general theory of interest, employment and money.London: McMillan.

[8] Khan HN (2015) Health care expenditure and economic growth in SAARC Countries (1995-2012): A panel causality analysis. Appl. Res. Q. Life (ISQOLS). 1-23

[9] Musgrave R, Musgrave P (1989) Public finance in theory and practice (5th ed). New York: McGraw-Hill International Editions, Finance Series

[10] Olugbenga AO, Owoeye O (2007) Public expenditure and economic growth: New Evidence from OECD Countries.

[11] Pesaran MH, Shin Y, Smith RJ (2001) Bounds testing approaches to the analysis of level relationships. Journal of Applied Econometrics 26:289-326

[12] Sánchez-Juárez I, Almada R, Bustillos H (2016). The relationship between total production and public spending in Mexico: Keynes versus Wagner. International Journal of Financial Research 7 (1): 109120.

[13] Schulz E (2004) Use of health and nursing care by the elderly. ENEPRI Research Report No. 2, CEPS, Brussels.

[14] Sims CA (1980) Macroeconomics and reality. Econometrica 48(1):148.

[15] Udo A, Effiong C (2014) Economic growth and Wagner's hypothesis: the Nigerian experience. Journal of Economics and Sustainable Development 5(16), 45-60.

[16] Udo A.B, Effiong C.E, Ogar O.O (2016) Economic growth of West African Countries and the validity of Wagner's law: a panel analysis. Asian Journal of Economics and Empirical Research 3(1):71-83.

[17] Wagner AH (1883) Three extracts on public finance. Translated and reprinted in R.A. Musgrave and A. T. Peacock (eds). Classics in the Theory of Public Finance, London: Macmillan.

[18] Wajid A, Kashif M (2016) Testing Wagner versus Keynesian hypothesis for Pakistan: the role of aggregate and disaggregate expenditure. MPRA, Munich Personal RePEc Archive 1-50.

[19] Wang L, Peculea AD, Xu H (2016) The relationship between public expenditure and economic growth in Romania: does it obey Wagner's or Keynes's Law? Theoretical and Applied Economics 41-52.

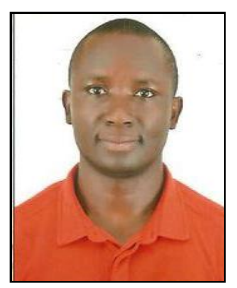

Saliu Mojeed Olanrewaju, (Ph.D) currently lectures in the Department of Economics, Ekiti State University, Ado-Ekiti, Nigeria. He is a Member of Nigerian Economic Society. His areas of research interest are Monetary and Industrial Economics

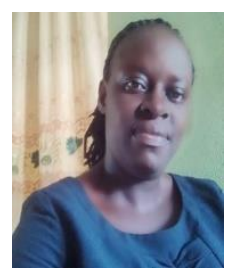

Akeju Kemi Funlayo, (Ph.D) lectures in the Department of Economics, Ekiti State University, Ado-Ekiti, Nigeria. She is a Member of Nigerian Economic Society. His area of research interest is Development Economics. 